\title{
Analisis Sosial dan Agama pada Praktik Pendistribusian Zakat Fitrah Bagi Dukun Bayi
}

\author{
Maskur \\ Sekolah Tinggi Agama Islam Wali Sembilan, Semarang, Indonesia \\ maskur2106128401@gmail.com
}

\begin{abstract}
Zakat fitrah is a compulsory zakat that muslims neet to do. Zakat fitrah should be made to Amil zakat or the committee appointed to handle zakat. This is so taht distribution is even and right on terget. This study aims to analyze socially and religiously so that a common thread will be obtained about the suitability of zakat distribution practices in research location. This research is a qualitative study that describes the data in detail based on the findings in the field. The distribution of zakat for the dukun in Jamus village can be analyzed from social and religious analyzes, in addition to gratitude for the people who have been helped by the dukun, also on average the dukun helps with a sense of sincerity and with great selflessness. The social analysis is understood that most of the people who give zakat fitrah to the dukun are because of their emotional closeness because they have been helped a lot by the dukuns. In this case social interaction is very well guarded. Broadly speaking, the social values practiced by most people are based on the values of sympathy, empathy, and respect. Religious analysis in the practice of distributing zakat fitrah to traditional birth attendants in the Jamus village becomes invalid if it is intended for zakat fitrah, but if the gift is in the form of shodaqoh or infaq it may be done.
\end{abstract}

Key words: Social; Religio; Zakat Fitrah; Dukun 


\begin{abstract}
Abstrak
Zakat fitrah merupakan zakat wajib yang perlu dilakukan oleh umat muslim. Zakat fitrah seharusnya dilakukan pada amil zakat atau panitia yang ditunjuk untuk menangani zakat. Hal ini agar pendistribusian merata dan tepat sasaran. Penelitian ini bertujuan untuk menganalisis secara sosial dan agama sehingga akan diperoleh satu benang merah tentang kesesuaian praktik pendistribusian zakat di lokasi penelitian Penelitian ini merupakan penelitian kualitatif yang mendiskripsikan data secara detail berdasarkan hasil temuan di lapangan. Pendistribusian zakat bagi dukun bayi di desa Jamus dapat dianalisis dari analisis sosial dan agama, selain pada rasa terimakasih bagi kaum yang pernah ditolong oleh dukun bayi, juga rata rata dukun bayi menolong dengan rasa ikhlas dan tanpa pamrih besar. Analisis secara sosial dipahami bahwa sebagian besar masyarakat yang memberikan zakat fitrahnya kepada dukun bayi karena adanya kedekatan emosional karena telah dibantu banyak oleh dukun bayi. Dalam hal ini interaksi sosial sangat dijaga dengan baik. Secara garis besar dari nilai-nilai sosial yang dilakukan sebagian besar masyarakat berdasarkan nilai simpati, empati, menghormati. Analisis agama dalam praktik pendistribusian zakat fitrah kepada dukun bayi di desa jamus menjadi tidak sah bila diniatkan untuk zakat fitrah, akan tetapi bila pemberian tersebut berupa shodaqoh atau infaq boleh dilakukan.
\end{abstract}

Kata kunci: Sosial; Agama; Zakat Fitrah; Dukun Bayi

\title{
A. Pendahuluan
}

Membayar zakat fitrah bagi kaum muslim merupakan hal yang wajib. Zakat adalah merupakan sebagian dari ibadah dalam kehidupan kaum Muslim (Setiawan, 2010). Ajaran Islam memiliki dua dimensi hubungan yang wajib dilakukan pemeluknya, yakni dimensi vertikal yang disebut dengan hubungan kepada Allah dan dimensi horizontal yang mewajibkan umat Islam membangun hubungan baik kepada sesama manusia. Hubungan baik dengan sesama manusia dimaksudkan untuk membangun kebersamaan dalam hidup bermasyarakat. Hubungan baik kepada sesama manusia tentu hanya dapat dilaksanakan dengan saling menjaga interaksi sosial. Adapun cara yang dapat dilakukan dalam kehidupan bermasyarakat yakni bisa dilakukan dengan saling menghormati, saling gotong royong, menjaga komunikasi baik antar sesama dan bisa pula dilakukan dengan saling memberikan hadiah. Dimensi horizontal pada dasarnya dapat dilakukan dengan mudah asalkan setiap individu dalam masyarakat memiliki kesadaran utnuk saling menjaga keharmonisan dan keselarasan hidup bermasyarakat. Apabila setiap individu menjalankan dimensi horizontal dengan baik maka tidak aka nada masalah dan konflik yang terjadi dalam masyarakat. 
Dimensi kedua yakni dimensi vertikal untuk menjaga hubungan manusia dengan Tuhannya. Dimensi ini biasanya dilakukan dengan melakukan berbagai ibadah yang sesuai dengan rukun Islam. Diantaranya yakni dilakukan dengan Shalat, Puasa, haji, dan ibadah lain yang berhubungan dengan manusia dan Tuhan. Zakat sebagai bentuk ibadah vertikal karena mengandung ketaatan Umat muslim terhadap Allah SWT juga memiliki makna sebagai bentuk ibadah untuk membangun hubungan baik dengan sesama manusia. Hal ini karena mengeluarkan zakat diperlukan niat untuk melakukannya dan ini membutuhkan keikhlasan untuk berbagi pula dengan orang-orang yang berhak menerima zakat.

Zakat fitrah merupakan zakat yang diperuntukkan untuk badan dan jiwa manusia. (Syarifuddin, 2003). Zakat fitrah ini merupakan penyempurnaan rukun Islam yaitu dilakukan setelah melaksanakan puasa Ramadhan selama satu bulan. Besaran yang harus dikeluarkan yakni makanan pokok dengan kadar atau ukuran satu sha', di Indonesia disepakati sebesar $2.5 \mathrm{~kg}$ beras atau bisa juga berupa uang senilai untuk membeli beras $2,5 \mathrm{~kg}$ tersebut. Untuk ketetapan makanan pokok tentu bisa menyesuaikan dengan makanan pokok berbagai daerah (Safitri, 2018) misalnya jagung, tepung, kurma, gandum, aqith dan makanan lainnya sehingga bukan hanya beras saja tetapi disesuaikan dengan makanan pokok yang biasa dikonsumsi di daerah tersebut. Untuk besarannya tentu harus diperhitungkan sesuai dengan nilai dari masing-masing kebutuhan pokok tersebut, yang kadangkala memang banyak perbedaan dalam menentukan besarnya zakat fitrah. The problem of comparative material, have not combined with religious theory in the learning process (Putra, 2018).

Pada dasarnya Islam sudah menetapkan bagi orang yang wajib menunaikan zakat fitrah (muzakki) adalah orang atau pribadi kaum muslimin dengan tidak membedakan baik itu orang merdeka dengan hamba sahaya, antara laki-laki dan perempuan, antara anak-anak maupun orang dewasa. Dengan demikian ketetapan bagi orang yang diwajibkan untuk membayar zakat adalah semua orang bahkan bagi bayi dan anak-anak sekalipun sudah ditentukan hukumnya untuk melaksanakan zakat fitrah ini. Kewajiban menunaikan zakat memiliki arti yang fundamental. Selain berkaitan erat dengan aspek Ketuhanan, zakat juga erat kaitannya dengan aspek penting dalam kehidupan baik itu sosial, ekonomi, dan kemasyarakatan (Raus, 2017).

Literasi muslim terkait zakat terdapat pada hadist nabi yang Artinya: "Sesungguhnya Rasulullah SAW. Telah mewajibkan zakat fitrah pada bulan Ramadhan atas orang-orang sebesar 1 sha $^{\text {ee }}$ kurma, atau 1 sah $^{\text {ee }}$ gandum, wajib atas orang merdeka, hamba sahaya, laki-laki dan perempuan, dari kaum muslimin.”(Muslim, 678.No hadits 984). 
Dikuatkan kembali melalui jalur Imam Bukhari bahwa oleh Bukhari dan Muslim dari Ibnu Umar r.a.:"Rasulullah s.a.w telah mewajibkan zakat fitrah dari Ramadhan sebanyak satu sukat dari kurma atau satu sukat padi, atas hamba dan orang merdeka, laki-laki dan wanita, anak kecil dan orang dewasa dari kaum muslimin (Sabiq, 1997). Ketetapan orang yang wajib dan orang yang berhak menerima zakat sudah diatur dalam Islam. Mustahidz adalah orang yang berhak untuk menerima zakat dalam Islam ketetapan fakir, miskin, ibnu sabil, fisabilillah dan sebagainya (Novansyah, 2015).

Fakta di lapangan menunjukkan hal lain berkaitan dengan pendidtribusian zakat, khususnya zakat fitrah. Ada kalanya pendistribusian tersebut tidak tepat sasaran karena bukan tergolong mustahidz atau orang yang berhak menerima zakat. Hal ini peneliti jumpai pada praktik pendistribusian zakat fitrah di Desa Jamus Kecamatan Mranggen Demak. Pendistribusian zakat yang cukup menarik yakni diberikan kepada dukun bayi yang notabene keberadaannya cukup mampu bila dibandingkan dengan masyarakat yang lebih membutuhkan contohnya buruh tani, pekerja serabutan, buruh cuci dan pembantun rumah tangga yang penghasilannya jauh di bawah dukun bayi.

Dukun bayi bagi sebagian besar masyarakat desa Jamus merupakan sosok yang familiar karena hampir sebagian besar pernah meminta bantuan untuk mengurus kelahiran maupun pasca melahirkan bagi sebagian besar keluarga yang ada di Desa Jamus Mranggen. Dukun bayi dianggap sebagai sosok yang membantu masyarakat karena membantu ibu dari semasa hami, melahirkan, setelah melahirkan bahkan sampai saat pertumbuhan dan perkembangan anak menuju masa remaja dan dewasa. Dukun bayi dianggap memiliki andil besar dalam masyarakat sehingga hampir semua masyarakat yang pernah dibantu memberikan zakatnya kepada dukun bayi tersebut.

Ada hal yang cukup menarik untuk dikaji terutama adanya tradisi sebelum menjelang lebaran atau pada saat pendistribusian zakat fitrah, banyak masyarakat yang berbondong-bondong menuju rumah dukun bayi untuk menyerahkan zakat fitrah. Dengan tangan terbuka para dukun bayi menerima dan sebagai ungkapan kedekatan akan dibalas dengan sekedar memijat balita yang dibawa oleh para pemberi zakat, memang proses memijat tersebut tidak lama durasinya hanya sekitar 3-5 menit saja sebagai syarat dan kesenangan mbah dukun bayi karena sudah bertamu di rumahnya.

Zakat fitrah seharusnya dilakukan pada amil zakat atau panitia yang ditunjuk untuk menangani zakat. Hal ini agar pendistribusian merata dan tepat sasaran. Melihat praktik penidtribusian secara langsung oleh masyarakat tentu ada kajian yang sangat menarik yakni dapat dianalisis secara sosial serta agama yang akan melihat praktik tersebut apakah sudah sesuai dengan hukum sosial dan agama Islam. Berdasarkan latar 
belakang tersebut peneliti tertarik untuk meneliti praktik pendistribusian zakat fitrah bagi dukun bayi di Desa Jamus Kecamatan Mranggen Demak.

Penelitian ini bertujuan untuk menganalisis baik secara sosial dan agama sehingga akan diperoleh satu benang merah tentang kesesuaian praktik pendistribusian zakat di lokasi penelitian.

\section{B. Pembahasan}

Penelitian ini merupakan penelitian kualitatif yang menelaah permasalahan penelitian secara lebih objektif (Martanti, 2015). Penelitian kualitatif dilakukan dengan membuat deskripsi, gambaran sistematis, faktual dan akurat mengenai fakta-fakta, sifatsifat serta hubungan antara berbagai fenomena yang diteliti secara mendalam (Martanti, 2018). Dengan melihat, melaah dan menyimpulkan permasalahan pendistribusian zakat fitrah bagi dukun bayi maka akan dapat diketahui kacamata sosial dan agama tentang praktik tersebut.

Data dalam penelitian ini merupakan data primer dan sekunder. Primary data or first-hand data are data obtained directly from research subjects (Martanti, 2020). Karena dari orang pertama maka diharapkan akan memberikan gambaran secara jelas tentang praktik pendistribusian zakat fitrah baik secara sosial dan agama. Data sekunder diperoleh selain dari orang pertama tetapi keberadaannya dapat membantu peneliti dalam menemukan banyak data di lapangan. Adapun data primer diperoleh dari hasil observasi, dokumentasi dan wawancara yang dilakukan kepada para informan. Sedangkan data sekunder dalam penelitian ini diperoleh dari data-data dari RT dan RW setempat yang sangat mendukung dalam penelitian ini. Teknik pengumpulan data dilakukan dengan observasi, dokumentasi dan wawancara. Hal ini tentu sesuai dengan teknik pengumpulan data secara kualitatif (Sukmadinata, 2010).

Zakat fitrah merupakan zakat yang diperuntukkan untuk badan dan dilaksanakan setiap akhir bulan Ramadhan (Syarifuddin, 2013). Zakat fitrah ini didistribusikan dengan prinsip utama untuk pemerataan dan keadilan antara kaum muslimin yang mampu dan yang tidak mampu. Pengelolaan zakat yang sesuai juga akan menurunkan angka meniskinan di masyarakat (Pratama, 2015).

Pada dasarnya tidak ada yang salah dalam pendistribusian zakat secara langsung dari orang yang wajib menunaikan zakat fitrah, hal yang tidak sesuai sebenarnya ada pada sasaran yang kurang tepat bila tidak didasarkan pada tinjauan agama. Membangun relasi baik dengan siapapun dan dimanapun sangat dianjurkan dalam agama Islam. Hal tersebut juga baik ibadah yang tidak boleh diabaikan oleh orang muslim. Berdasarkan hasil penelitian dapat diketahui bahwa kesadaran masyarakat untuk menunaikan zakat di 
Desa Jamus memang sangat baik. Hal ini dapat dilihat dari semua orang yang memiliki kewajiban zakat menunaikan semua kewajibannya sesuai dengan ketentuan dalam agama Islam. Kesadaran berzakat merupakan hal penting dalam pelaksanaan zakat bagi kamun mislim akan tetapi dalam praktiknya harus pula dibarengi dengan pemahaman tentang zakat itu sendiri. Masyarakat harus diberikan edukasi terkait hukum, kearifan zakat sehingga dalam pelaksanaanya sesuai dengan nilai sosial maupun nilai agama. (Nurkhasanah, 2018).

Dukun bayi yang membantu persalinan. di Desa Jamus berjumlah 2 orang. Dukun bayi ini bahkan membantu dari sejak ibu hamil, melahirkan, membantu ketika anak sakit hingga masa pertumbuhan remaja bahkan dewasa. Andilnya cukup besar dalam membantu masyarakat sehingga keberadaanya cukup dekat dengan masyarakat. Gambaran profil dukun bayi di desa Jamus cukup terkenal dan cukup banyak membantu bahkan tidak hanya satu desa hingga ke desa lainnya bahkan ke kota Demak maupun Semarang. Eksistensinya cukup penting dan bukan profesi yang mudah dilalui karena memerlukan keterampilan tersendiri. Dukun bayi dituntut untuk memiliki keterampilan yang mumpuni untuk memijat, mengurus ibu yang melahirkan dan mengurus bayi bahkan dituntut untuk memiliki kemampuan sebagai orang tua yang ahli dalam spiritual dan hal-hal yang berbau paranormal. Sebagai contoh bila ada bayi yang rewel dan dianggap terkena "sawanan" biasanya akan dibawa ke dukun bayi. Bayi yang rewel dalam pandangan sebagian masyarakat karena adanya ganguan makhluk halus sehingga butuh penangganan khusus dan ini diyakini hanya dukun bayi yang mampu mengatasinya. Belum lagi bila ada anak yang jatuh, sakit yang tidak kunjung sembuh juga menjadi tugas dukun bayi untuk mengatasinya.

Dukun bayi yang ada di desa Jamus cukup lama menggeluti profesinya bahkan menurut penuturan Mbah Y sebagai dukun bayi sudah hamper 40 tahun. Untuk menjadi dukun bayi perlu keterampilan khusus dan bahkan diperlukan belajar yang cukup lama yakni hampir sepuluh tahun. Pada awalnya dukun bayi merupakan asisten dukun bayi sebelumnya atau memiliki keturunan secara langsung dari dukun bayi. Dengan demikian tidak semua orang dapat menggeluti profesi ini terlebih lagi membutuhkan keterampilan, ketelatenan dan kesabaran dalam membantu masyarakat. Setiap orang memiliki permintaan sendiri-sendiri kadang ada yang cukup banyak permintaan meski ada pula yang tidak terlalu menuntut lebih dari jasa dukun bayi. Dukun bayi yang ada di Desa Jamus secara finansial mampu menghidupi keluarga bahkan menjadi penopang utama keluarga. Memang tarif untuk memijat atau memberikan pelayanan tidak dipatok secara resmi, sehingga bila ada masyarakat yang tidak mampu membayar dengan uang biasanya akan memberi dengan barang-barang lain seperti beras, gula, kopi, minyak atau tepung. 
Tak jarang dukun bayi malah memberikan jasanya secara gratis kepada orangorang yang benar-benar tidak mampu membayar dalam bentuk uang atau barang. Menurut penuturan Mbah Y untuk tarif pijat atau jasa membuat sawanan untuk bayi memang tidak dipatok secara resmi akan tetapi untuk mengurus bayi yang baru lahir, baik itu memandikan bayi, memijit dan melakukan perawatan bayi selama 40 hari memang ditarif tetapi itupun tidak menjadi patokan dalam menjalankan tugas, bila tidak mampupun dukum bayi juga tidak memaksa. Prinsip bekerja dukun bayi yang ada di Desa Jamus Mranggen berdasarkan asas suka rela dan diniati untuk membantu sesame terutama bagi orang-orang yang membutuhkannya. Meski tidak mematok tarif secara resmi, akan tetapi bila dihitung penghasilan dukun bayi tidak bisa dipandang sebelah mata, hal ini karena masyarakat yang membutuhkan bantuannya cukup banyak maka tak heran bila dihitung secara keseluruhan penghasilan dukun bayi tergolong cukup besar.

Keberhasilan menjadi dukun bayi secara ekonomi nampak dari kemampuan membeli sejumlah asset berupa tanah, mampu menyekolahkan anak hingga mampu menunaikan ibadah umroh. Tidak jauh berbeda dengan Mbah A yang menekuni profesi dukun bayi selama puluhan tahun juga menjadi penopang utama bagi keluarganya. Selain mampu mencukupi kebutuhan hidup sehari-hari, mampu menyekolahkan anakanaknya hingga jenjang perguruan tinggi dan mampu memiliki sejumlah asset penting seperti tanah dan asset lain yang dimilikinya. Selain itu juga mampu digunakan untuk menunaikan kewajiban haji yang telah dilaksanakan beberapa tahun yang lalu.

Melihat gambaran dukun bayi di desa Jamus nampak bahwa secara ekonomi tergolong mampu. Bahkan bila dibandingkan dengan masyarakat lain tergolong cukup kaya. Hal ini selain dukun bayi mampu menghidupi dirinya sendiri bahkan keluarganya, dukun bayi juga mampu mengembangkan hartanya uttuk berisvestasi. Dengan demikian secara hukum agama dukun bayi di Desa Jamus bukan merupakan orang yang berhak menerima zakat. Terutama masih ada masyarakat yang jauh lebih tidak mampu bila dibandingkan dukun bayi. Zakat yang didistribusikan secara benar pada dasarnya merupakan salah satu cara untuk mengurangi kemiskinan (Nasrullah, 2010). Dengan demikian pemahaman zakat bagi masyarakat desa Jamus perlu diperbaiki sehingga tujuan zakat yang semestinya dapat terlaksana dengan sebagaimana mestinya.

Pendistribusian zakat fitrah juga dapat dilakukan melalui amil zakat yang ditunjuk sehingga pendistribusian dan pendayagunaan zakat dapat terlaksana secara maksimal (Bahri, 2020). Peran perangkat desa tentu perlu diupayakan agar memahamkan masyarakat dan mengatur pendistribusian zakat sesuai dengan kaidah agama yang benar. Bila dilakukan secara mandiri tetapi dalam pendistribusiannya tidak sesuai maka sebaiknya dikelola desa dan didistribusikan sesuai ketentuan agama yakni diutamakan bagi orang-orang yang berhak menerima zakat tersebut. 
Analisis secara sosial dipahami bahwa sebagian besar masyarakat yang memberikan zakat fitrahnya kepada dukun bayi karena adanya kedekatan emosional selain alasan telah dibantu banyak oleh dukun bayi. Dalam hal ini interaksi sosial sangat dijaga dengan baik. Berdasarkan keterangan beberapa masyarakat yang lebih suka memberikan zakatnya secara langsung kepada dukun bayi karena alasan mempertahankan tradisi yang sudah ada yakni memang sudah umumnya sebagian masyarakat memberikan zakatnya kepada dukun bayi apalagi yang memiliki balita dan telah banyak dibantu dukun bayi. Sementara itu penuturan lain juga disampaikan bahwa satu alasan memberikan zakatnya kepada dukun bayi dengan alasan sudah terbiasa pijat dan minta bantuan kepada dukun bayi. Selain itu ada pula alasan menghormati dukun bayi karena sudah besar jasanya dalam membantu sebagian masyarakat.

Secara garis besar dari nilai-nilai sosial yang dilakukan sebagian besar masyarakat berdasarkan nilai simpati, empati, menghormati dan nilai kebersamaan yang dilakukan. Tidak ada yang salah dalam menjaga nilai-nilai baik yang ada di masyarakat sehingga perlu dilestarikan dan diberdayakan dapat lebih dilakukan oleh semua masyarakat. Akan tetapi melihat nilai-nilai sosial tersebut tidak serta merta dijadikan pedoman dalam pendistribusian zakat khususnya zakat fitrah. Hal tersebut selain karena menjaga interaksi sosial dan menjalankan kewajiban membayar zakat merupakan hal yang berbeda terutama dari segi sosial dan agama yang kadang tidak bisa disamakan meski tujuan zakat salah satunya untuk mengembangan kehidupan sosial dalam kehidupan masyarakat.

Menjaga keharmonisan kehidupan masyarakat merupakan hal yang wajib dilakukan oleh semua orang tetapi dasar dan pelaksanannya tentu tidak bisa disamakan dalam menjalankan kewajiban sebagai umat beragama, khususnya umat muslim. Menjaga hubungan sosial dan agama bila dianalogikan seperti dua sisi mata uang, meski berdekatan tetapi ada sudut pandang yang berbeda yang harus digunakan. Menjaga interaksi sosial yang baik dapat saling dilakukan dengan saling menghormati, menyayangi, membantu dan bisa juga dilakukan dengan saling memberikan hadiah atau dalam konteks agama hadiah tersebut bisa disebut infaq atau shodaqoh. Dalam agama memberikan infaq dan shodaqoh ini keutamaannya sangat besar bahkan menjadi anjuran kepada seluruh umat muslim. Keberadaan infaq dan shodaqoh selain sebagai upaya untuk menjaga keharominisan hubungan masyarakat, juga berfungsi untuk membantu sesama terutama bagi yang membutuhkan. Pada dasarnya antara infaq dan shodaqoh bila dikaitkan dengan ketentuan zakat jelas berbeda. Bila dilihat waktu pelaksanaannya infaq dan shodaqoh bisa dilakukan kapanpun tanpa ada batasan waktu. Hal demikian berbeda dalam ketentuan zakat ada waktu yang diwajibkan untuk memberikan zakat misalnya untuk zakat fitrah dilakukan dalam bulan Ramadhan, zakat ternak bila sudah 
memenuhi jumlah yang perlu dizakatkan, zakat emas bila sudah mencapai nisabnya dan zakat-zakat lain yang ditentukan dalam agama.

Memberikan infaq dan sedekah berdasarkan ketentuannya tidak dibatasi jumlahnya asalkan dilakukan dengan penuh keikhlasan akan tetapi berbeda dengan zakat, ketentuan jumlah sudah diatur dalam agam secara rinci. Misalnya saja ketentuan zakat fitrah sudah jelas di Indonesia disepakati sebesar $2.5 \mathrm{~kg}$ beras atau bisa juga berupa uang senilai untuk membeli beras $2,5 \mathrm{~kg}$ tersebut. Ketetapan jumlah tersebut jelas tidak bisa dikurangi atau ditambah. Bila dikurangi maka akan membuat hukum zakat menjadi tidak sah. Apabila dilebihkan sebenarnya apa yang menjadi kelebihannya tidak termasuk zakat melainkan termasuk infaq atau shodaqoh.

Berdasarkan analisis agama terkait pendistribusian zakat fitrah kepada dukun bayi di desa Jamus Mranggen Demak dapat diketahui bahwa dukun bayi bukan termasuk orang yang berhak memperoleh zakat fitrah hal ini karena keberadaan dukun bayi secara finansial sangat mampu dan masih banyak yang jauh membutuhkan zakat fitrah tersebut. Bila niat orang yang memberikan adalah untuk zakat fitrah maka hukumnya bisa tidak sah karena tidak memenuhi ketentuan dalam berzakat. Pemberian yang diberikan kepada dukun bayi lebih tepatnya berupa infaq atau shodaqoh sebagai tanda kasih sayang dan ungkapan terimakasih kepada dukun bayi. Pada dasarnya analisis secara sosial dan agama dari pendidtribusian zakat fitrah bagi dukun bayi dapat dipahami melalui tabel 1 dan tabel 2 berikut ini:

Tabel 1. Analisis secara Sosial Pendistribusian Zakat Fitrah bagi Dukun Bayi

\begin{tabular}{cll}
\hline No & & Analisis Secara Sosial \\
\hline 1. & Nilai Simpati & \\
\hline 2. & Nilai Empati \\
\hline 3. & Nilai Menghomati & \\
\hline 4. & Nilai Kebersamaan & \\
\hline Sumber: Data Penelitian
\end{tabular}

Tabel 2. Analisis secara Agama Pendistribusian Zakat Fitrah bagi Dukun Bayi

\begin{tabular}{cl}
\hline No & \multicolumn{1}{c}{ Analisis Secara Agama } \\
\hline 1. & Tidak ada larangan pemberian zakat bagi dukun bayi \\
\hline 2. & $\begin{array}{l}\text { Pendistribusian zakat harus sesuai dengan orang-orang yang } \\
\text { berhak menerima zakat }\end{array}$ \\
\hline 3. & $\begin{array}{l}\text { Pemberian sesuatu kepada dukun bayi yang diniatkan sebagai } \\
\text { zakat fitrah menjadi tidak sah }\end{array}$ \\
\hline 4. & $\begin{array}{l}\text { Pemberian sesuatu kepada dukun bayi bila diniatkan sedekah atau } \\
\text { infaq boleh dilakukan }\end{array}$ \\
\hline
\end{tabular}

Sumber: Data Penelitian

Ijtimaiya: Journal od Social Science Teaching 


\section{Simpulan}

Simpulan dalam penelitian ini adalah untuk menjawab analisis dari sosial dan agama terkait pendistribusian zakat fitrah. Secara sosial dalam pendistribusian zakat fitrah bagi dukun bayi di desa Jamus berdasarkan nilai simpati, empati, menghormati dan nilai kebersamaan yang dilakukan. Pendistribusian zakat fitrah bagi masyarakat Jamus Mranggen juga sebagai upaya menjaga tradisi yang sudah dilakukan secara turun temurun dan sebagai bentuk terimakasih yang bisa dilakukan oleh sebagian masyarakat yang telah dibantu dukun bayi. Tidak ada yang salah dalam menjaga nilai-nilai baik yang ada di masyarakat sehingga perlu diberdayakan agar dapat dilakukan oleh semua masyarakat. Berdasarkan analisis secara agama dapat dipahami bahwa pendistribusian zakat fitrah bagi dukun bayi pada dasarnya tidak dilarang akan tetapi harus sesuai ketentuan agama yakni termasuk dalam orang-orang yang berhak menerima zakat fitrah. Analisis agama terkait pendistribusian zakat fitrah kepada dukun bayi di desa jamus menjadi tidak sah bila diniatkan untuk zakat fitrah, akan tetapi bila pemberian tersebut berupa sedekah atau infaq boleh dilakukan. Bila ketentuan tersebut tidak dipahami oleh orang yang berzakat maka zakat tersebut bisa tidak sah secara hukum agama tetapi pemberian tersebut bisa termasuk infaq atau shodaqoh saja. Saran bagi peneliti selanjutnya yaitu untuk bisa melalukan penelitian yang jauh lebih luas wilayahnya sehingga akan menjadi semakin menarik dan nilai kemanfaatan dari penelitian akan semakin besar

\section{DAFTAR PUSTAKA}

Bahri, E., S., \& Khumaini, S. (2020). "Analisis Efektivitas Penyaluran Zakat Pada Badan Amil Zakat Nasional." AL Maal 1 (2).

Martanti, F. (2020). "Integration Of Aswaja Teaching: Concept Of Strengthening Character Education in College." Tawasut, 7(1).

Martanti, F. (2018). "Metode Struktural Analitik Sintetik Dalam Pembelajaran Anak Disleksia." Albidayah 10(1), 17-28.

Martanti, F. (2015). "Peran Furu Kelas Dalam Memberikan Layanan Bimbingan Dan Konseling Di SDN Watuaji 01 Kabupaten Jepara.” Magistra 6(2).

Muslim, HR II. n.d. Sohih Muslim. II.

Nasrullah, M. (2010). "Peran Zakat Sebagai Pendorong Multiplier Ekonomi." Jurnal Huтum Islam 8 (1).

Novansyah, A., Sunardi, H., \& Ramadhan, R. (2015). “Sistem Informasi Pengolahan 
Zakat Dan Infaq Pada Masjid Agung Palembang.” Jurnal Informatika Global 6 (1).

Nurkhasanah, S., \& Suryani. (2018). "Maksimalisasi Potensi Zakat Melalui Peningkatan Kesadaran Masyarakat.” Jebi 3 (2).

Pratama, Y., C. (2015). "Peran Zakat Dalam Penanggulangan Kemiskinan (Studi Kasus: Program Zakat Produktif Pada Badan Amil Zakat Nasional)." TAUHIDINOMICS 1 (1).

Putra, Y., Y., \& Saputra, A. (2018). "The Applying of Hypothetical Learning Trajectory (HLT) on Comparison Material Using Nisab Zakat Theory toward The Student's Learning Outcomes." Jurnal Aljabar 9 (2).

Sabiq, S. (1997). Fikih Sunnah Jilid 3. Bandung: PT, Al Ma'arif.

Safitri, I., U. (2018). "Problematika Zakat Fitrah.” Tazkiya 19 (1)

Setiawan, D. (2011). “Zakat Profesi Dalam Perdagangan Islam”. Jurnal Sosial Ekonomi Pembangunan, 1(2), 195-208.Syarifuddin, Amir. (2003). Garis-Garis Besar Fiqh. Jakarta: Prenada Media.

Sukmadinata, N., S. (2010). "Metode Penelitian Pendidikan”, Bandung: PT. Remaja Rosdakarya.

Syarifuddin. 2013. “Zakat Fitrah (Kajian Hadis Tematik).” Alhikmah 14 (1).

Raus, W., N., A. (2017). "Perilaku Pasangan Yang Baru Menikah Dalam Menunaikan Zakat Fitrah.” Jurnal Ziswaf 4 (1). 
